\title{
PRESENT OF TRADITIONAL TALES LIVING FORMS
}

\author{
Bakhodir Mamajanovich Rakhmanov \\ $\mathrm{PhD}$ in Philology, \\ Associate Professor of Andizhan State University, \\ Andizhan region, \\ Republic of Uzbekistan
}

Article DOI: https://doi.org/10.36713/epra4878

\begin{abstract}
The article provides an extensive analysis of the current living forms of traditional fairy tales. The question of the survival of traditional fairy tales has not been studied at all in our folklore. Besides, it is inevitable that this issue will be the focus of our fairy-tale studies with all its contradictions and complexity. It identifies a number of components that make up the process of living the fairy tale.
\end{abstract}

KEY WORDS: traditional fairy tales, fiction, fairy tale genre, literary tales, figurative tales.

\section{INTRODUCTION}

A genre that reflects fairy-tale reality in its own fiction in the pattern of real reality, through the activities of individual heroes in a specific space and time. It embodies the people's desire for a bright future, a free and prosperous life. Knowing that the events, heroes, countries and times depicted in the fairy tale are pure fiction, we rush to listen to it, to get spiritual strength, emotional pleasure from it. What is the reason for this? We believe that the reason for our interest in fairy tales is that our ancestors embraced our centuries-old dreams in the form of imaginary fictional events depicted in it. In the distant past and in the present, when people are tired of the worries of real life, when the injustices of the cruel world tear their hearts apart, when the pains of unrequited love make bitter tears fall from their eyes, when they sink into the ocean of despair. It turns out that the power of the noble ideas in it makes fairy tales a respected genre all the time and everywhere. It is only with this feature that fairy tales have always been valued.

\section{METHODS}

It is well known that the fairy tale genre, with its formal possibilities, image system, amazing fiction, traditional epic space and time coverage, stable formulaic artistic language, cannot reflect the worldview, spiritual world, dreams and aspirations of modern people in all their complexity and versatility.
Because, the problems of modern life and human relations do not fit into the poetics of fairy tales. So, when thinking about the current state of traditional fairy tales, it would be correct to speak with a clear distinction between the two issues. These are a) recreation of fairy tales; b) issues of the survival of traditional fairy tales. There is no doubt that the genre of fairy tales has now ceased to fully reflect the new reality. Because, on the one hand, the audience's aesthetic perception of reality has changed. Modern people are not satisfied with fairy-tale fiction, mythological images and interpretations. On the other hand, the artistic form of the fairy tale, the poetic criteria, has now become an undeniable aesthetic law that lags behind the requirements of artistic creation. In this sense, the fairy tale has become the property of only children and adolescents.

\section{RESULTS AND DISCUSSIONS}

The fascinating fantasy in fairy tales, the supernatural magical image has become a rare artistic phenomenon even today, undoubtedly having a significant impact on the strengthening of children's imagination, enriching their spiritual world. The conclusion to be drawn from the above is that now the problem of creating fairy tales has solved itself. The creation of a fairy tale that fully reflects the new reality cannot convince anyone. But traditional tales which are equally pleasing to all, must be preserved 
in the memory of mankind as a spiritual and moral value. As such, it is natural that the question of the living forms of traditional fairy tales emerges from the agenda as an aesthetic necessity today. The question of the survival of traditional fairy tales has not been studied at all in our folklore. So, it is inevitable that this issue, with all its contradictions and complexity, will be the focus of our fairy tales. If we say that the living existence of the fairy tale genre is a holistic process, we must also have a certain idea about the components that make up this process, the components that move them. In our opinion, the personality of the narrator plays an important role in the living life of the fairy tale. He creates fairy-tale material with his talent, amazing memory, narrates it with a unique skill. It is not enough to say that it speaks for itself. Because a true storyteller's performance is rich in rhetoric, behavior, facial expressions, gestures, and intonation, such a performance is very different from just telling a story. In addition, the skillful storyteller ensures the continuity of the performance with fiction without violating the artistic-semantic canons of the fairy-tale genre, thereby completely tying the listener's attention to the fairy-tale events. In this sense, there are very few talented storytellers left today. The second component of a fairy tale live performance is the audience. The integral connection between the narrator and the listener is an important factor in ensuring the survival of the genre. While the listener plays a defining role in the full expression of the storyteller's skill, the storyteller's ability to lead in satisfying the listener's interests and needs takes the lead. In short, these two components are in a dialectical relationship with each other. While the needs of the listener inspire the performer, the skill of the narrator brings joy to the listeners, giving them spiritual pleasure. By the twentieth century, the scientific worldview of the listener of fairy tales had grown, and his consciousness had grown even more. Now he began to strive to understand the natural, social causes of any fantasy and fiction, to accept the essence of any event and phenomenon through social, psychological determinism. As a result, scientific acceptance began to take the lead in the listener's perception, replacing the imaginary perception of the fairy-tale world. This extinguished the aesthetic need for the fairy tale genre.

The third component that makes up the living life process of a fairy tale is the direct story material. This component consists of a conditional artistic reality that has the power to captivate both the performer and the listener. But the reality in which both components lived did not provide the appropriate material for the tale. The rapid development of science and technology, the drastic change in the worldview of listeners, the introduction of radio, television, cinema and fiction began to hinder not only the creation of fairy tales based on fiction and science fiction, but also its acceptance. As a result, the creation and performance of the fairy tale genre almost came to a standstill. The fairy tale became the property of children and teenagers. Under such conditions, the lifestyles of fairy tales also changed. Because, it is natural that the people will not allow the complete disappearance of this great spiritual and cultural value created by their genius. It was from this demand that the discovery of the various forms that sustained the genre of fairy tales ensured its survival. They are, in our view, the following. 1. It is known that folk tales have been written for many years by folklorists, amateurs and intellectuals, university students, writers and poets. The text of the recorded fairy tales is mainly stored in the folklore archive of the Institute of Uzbek Language, Literature and Folklore of the Academy of Sciences of the Republic of Uzbekistan, as well as in the literature departments of philological faculties of higher educational institutions. This charitable movement was revived in the 20 s and 30 s of the last century due to folklore and ethnographic expeditions to various regions. As a result, a great legacy of famous storytellers such as Husanboy Rasulov, Nurali Nurmat ugli, Haydar Boychaev, Boynazar Beknazarov, Abdugafir Shukurov, Rahmatilla Yusuf ugli Jabbor Chorikulov has been accumulated. In this work Gaziolim Yunusov, H.Zarif, M.Afzalov, J.Kobulniyozov, O.Sobirov, Yu.Sultonov, K.Imamov, Z.Husainova, T.Mirzaev, B.Sarimsakov, A.Musokulov, Sh.Turdimov. The services of such scientists as Juraev, M. Murodov, H. Rasul, H. Razzakov, T. Gazibaev were great. The significance of this work, which now seems simple to us, in the history of our culture is enormous. Because, first of all, the fairy-tale heritage of an entire nation, which is disappearing without a trace only due to the collection of folklore, has been recorded and preserved in the folklore archive and other funds, as well as in personal archives. Second, most of the recorded tales were published in separate editions, especially in large numbers under the series "Uzbek folk art". These publications have made a great contribution to acquainting our people with the masterpieces of our fairy-tale heritage, to educating the younger generation on the basis of high ideals. Even in the current situation, when reading has slowed down, the interest in folk art, especially folk tales is still high. This fact shows that at a time when the masses of the people are literate, the publication of beautiful ideological and artistic samples of our fairy tale heritage in the form of specific collections, their widespread dissemination is the most effective, most popular means of modern life of the fairy tale genre. It is well known that the practice of publishing fairy tales in the form of collections of fairy tales written in the history of Western European, Russian, Ukrainian and Belarusian cultures, which ended before us, has already paid off. The three-volume 
"Russian Folk Tales" published by the famous ethnographer Afanasev is exemplary in this respect. However, it should be noted that in the publication of fairy tales, there are cases of artificial interference with the text, editorial corrections, listening to the fairy tale and then writing it down on the basis of literary language norms, which spoils the originality of folk tales. In addition, instead of searching for unpublished samples of folk tales and publishing them, there are cases of selection of fairy tales from previously published collections, their processing and publication, which is not only falsification of folk art history, its past and worldview not something. Of course, today the work of publishing fairy tale collections has slowed down considerably. Because, finding sponsors for publications, the fact that the published product reaches the reader at a high price, has a negative impact on the development of the publication of fairy tales. Therefore, only professionals who are well acquainted with the secrets of the genre, its delicacy, have the right to deal with the publication of fairy tales. Only in this way can the publication of fairy tales be fully convinced that the genre lives in the same form.

2. Traditional folk tales, with their semantic weight, educational and pedagogical significance, enlightenment significance, always arouse great interest in people's lives. This is why people approach this genre with different attitudes in their daily lives. One such form of appeal is the broadcast of "Okshom ertaklari" on the radio. On TV, the program "Good night, little ones" is regularly broadcast. In both programs, small didactic fairy tales are shown or films based on fairy tale plots are shown. Films such as "Zumrad and Kimmat" and "Egri with tugri" are among them. This thing, on the one hand, plays an important role in the upbringing of children, on the other hand, allows the fairy tale genre to live actively in life, to keep it from being forgotten. This means that the existing examples of fairy tales, which have ceased to be re-created, serve as an inexhaustible source of information in the work of educating young people in a high spiritual and moral spirit through the opportunities of the media, such as radio and television. Raising this process to the level of modern requirements depends on the joint work of folklorists, educators and media professionals.

3. The creation and public display of feature films, cartoons based on the plot of folk tales is also one of the forms of life of traditional fairy tales. Feature films such as "Tahir and Zuhra", shot in the 30 s and 40 s of the last century, and later "Alpomish" were met with great interest by the public. Frankly, folk tales and epics are an inexhaustible treasure for cinematography. But filmmakers are not making good use of this treasure. If films were made based on the plots of magical fairy tales, not only cinematography but also the living forms of folk tales would be enriched. Unfortunately, this is not something that is pleasing to the eye. But over the years, it is natural that the demand and need of the people for the spiritual values created by them will increase. So, in the future, one can hope that many films will be created on the basis of beautiful examples that make up amazing examples of folk fantasy. This would have enriched the living forms of traditional folk tales by another means

4. Fairy tales are an invaluable spiritual value with their closeness to the world of children, enriching their imaginary world. Enriching the spiritual world of the younger generation means educating a perfect person and being responsible for the future. Therefore, the demonstration of folk tales among young people in various ways, the enlightenment of children with their noble ideas should be the primary task of theatrical artists, especially actors of young audience theaters. Only fairy tales can absorb into the minds of children the essence of the eternal struggle between good and evil, the inevitability of the victory of good in this struggle to such an extent that they will be remembered for a lifetime. The vitality, simplicity and naturalness of domestic fairy tales are extremely suitable for scenes for children and teenagers. Because in everyday fairy tales there are very few serious philosophical problems that are difficult for young people to understand. This does not cause too much difficulty for the director and the actors in the stage interpretation of household tales. Figurative tales are also close to everyday tales in this respect, and even surpass them in some respects. Because the characters in figurative fairy tales are mainly animals, the closeness of animals and their behavior to the world of children allows these types of fairy tales to be received with great interest in children's theaters. That is why it is natural for children to watch theatrical performances based on the plot of fairy tales, not once, but again and again, to enjoy them, to imitate them.

Demonstration of the above two types of folk tales among children and adolescents, firstly, allows the best examples of fairy tales to live among young people, and secondly, to enrich children's minds with vivid ideas of fairy tales, to support their aspirations for the future, ie youth helps to enrich our fighting optimism in the spirit. At the same time, theatrical performances for children and adolescents help young people to clearly and early discern the commonalities and differences of real life with fairy tales. In any case, staging folk tales for children is a tool that allows some works of the fairy tale genre to live, and this tool should be used effectively.

5 . The activities of amateur art groups, mass ethnographic ensembles are also inextricably linked with the genres of folk art. Their repertoire includes stage performances of folk songs, lapar and olan, askiya and fairy tales. Because amateur art groups 
often develop by interpreting folklore materials in terms of modern requirements. In the following years, ethnographic ensembles of each region were formed. They include a number of local intellectuals and workers of various professions, as well as people who are well versed in various fields of folk art. An important role should be played in the direction of their activities, the organization of stage performances based on the motives of folk legends and myths, fairy tales and anecdotes, along with various genres of folk art. Because the main purpose of folklore ethnographic ensembles should also be to demonstrate the power of folk creative genius. Folk art, on the other hand, covers not only the present, but also the past and the future. The implementation of the above depends on the efforts of the leaders of folklore and ethnographic ensembles, methodologists. First of all, they need to know and feel the high ideological and artistic value of folk tales, their invaluable spiritual value. Realizing the immense role of fairy tale material in enriching the worldview of young people, developing their creative imagination, cultivating their attitude to life and people, firstly, ensures the current activity of the genre, and secondly, the development of amateur art groups, folklore and ethnographic ensembles. 6 . Folk tales attract not only the noble ideas, but also the representatives of the written literature with their amazing fiction, charming form and astonishing fiction. The formulaic image of fairy tales, the unique nature of space and time, the constant resolution of conflict in favor of good, led to the creation of works of art that help to educate the younger generation in the spirit of diligence, patriotism and humanity. Such works are called literary tales. Literary fairy tales are didactic works created by individual artists in the form of folk tales, focused on current issues of the time, often on the education of young people. More precisely, a literary fairy tale is a work created by a poet or a writer on the basis of the plot and motives of traditional folk tales, their formal properties. There are many commonalities and differences between literary folk tales and traditional folk tales created orally. What they have in common is that literary tales also contain a formulaic narrative typical of traditional tales, as well as fiction, rhetoric, and fiction. Literary tales also begin with initial formulas such as 'as long as there aren't', changes in space and time are also described with exaggerated medial formulas as in traditional tales, and each work always ends with a successful solution. In literary fairy tales, no matter how much the creator appeals to the stable formulas inherent in traditional fairy tales, the content of the events in each fairy tale is dominated by individual uniqueness in their artistic interpretation. The tradition of creating literary tales is quite ancient, and their roots go back to the literature of nations that had previously lost the creation of traditional tales. For example, the Danish writer Hans Christian Andersen (1805-1875), the German philologists, the brothers Jacob (1785-1863) and Wilhelm (1796-1859) Grimm reworked folk tales in a literary way, and they themselves wrote many literary tales in the form of folk tales. creators. The literary tales they created are still loved and read by many. Literary tales created by Hans Christian Andersen differ from traditional tales on the one hand, in contrast to fiction in traditional folk tales, by bringing the protagonists closer to real reality and giving them reality, and on the other hand, giving real life objects and events a fantastic look.

The protagonists of the literary tales created by the Brothers Grimm are the children of peasants, artisans, poor laborers from the common people, who are notable for their diligence, intelligence, meticulousness, vigilance, and humanity. One of the great contributors to the treasury of world literary tales was the French poet and critic Charles Perrault (1623-1703), whose tales "The Red Riding Hood", "The Sleeping Beauty", "The Naughty Girl", and "The Cat in the Boots" turned into fairy tales. He managed to increase the readability of his fairy tales by using the pleasant humor and sarcastic laughter typical of folk art. In the genre of literary fairy tales in Russian literature N.M.Karamzin, V.A.Zhukovsky, A.S.Pushkin, P.P.Ershov, V.F.Odoevsky, S.T.Aksakov, V.I.Dal, K.D. .Ushinskiy, D.N.MaminSibiryak, L.N.Tolstoy, A.M.Gorkiy, A.N.Tolstoy, V.V.Bianki, E.L.Shvarts, K.G.Paustovskiy. Many poets and writers, such as Gaidar, M.E. SaltukovHedrin, K. Chukovsky, have created rich works. In Uzbek literature, beautiful examples of literary tales have been created by such writers and poets as $H$. Olimjon, Z. Diyor, S. Jura, Sh. Sadulla, A. Rahmat, P. Mumin, M. Azam, T. Adashbaev. There are many opinions about the genre features of literary fairy tales. In particular, the Russian scholar L. Braude argues that literary fairy tales are a separate genre based on the fiction inherent in traditional folk tales, on the one hand, and on the artistic texture of the individual artist, on the other hand [1, p.234]. S.Ya.Serov emphasizes the connection of literary fairy tales with folklore and written literature. He rightly admits that literary fairy tales are notable for being intended primarily for children and adolescents [2, p.3-116]. For this reason, literary fairy tales are often found in the works of representatives of children's literature. Because fairy-tale fiction, a supernatural fictional plot, is more interesting for children and teenagers than for adults. In addition, most literary tales have instructive content, which is important for the spiritual and moral development of children. Well-known Russian folklorist V.P. Anikin also noted that a literary fairy tale is a literary phenomenon that stands between folklore and written literature, linking them to each other correctly shows that it can be a topic for [3, p.22]. Uzbek literary tales have been specially studied by folklorist S. Alimov. 
In his view, literary fairy tale is a genre of written literature. Well-known Russian literary critic V.I.Novikov and Russian folklorist E.V. Pomerantseva also believe that fairy tales written by a poet or writer in close connection with the theme, plot and motives of folk tales should be considered literary tales, they are the property of literature, not folklore correctly note that $[5, \mathrm{p} .356-357]$. We also fully agree with the views of the scholars named above. This is because literary fairy tales derive their narrative style, fiction, formulas, and artistic conditionality from traditional folk tales, but retain the individuality inherent in written literature. It would therefore be more correct to look at and evaluate a literary tale as a phenomenon relating to written literature rather than to folklore. In addition, as the folklorist and literary critic M.A. Azadovsky rightly points out, any writer or poet who touches on a literary fairy tale reworks the material in accordance with his own views, giving it a new content and essence. In this way, a literary fairy tale becomes a pure national work of the artist's own work, if the material on which the fairy tale is based belongs to another nation [7, p.298-304].

This feature applies not only to Russian literary tales, but also to the literary tales of all nations. Written literature developed on the basis of many epic genres of folk oral art. That is why in the written literature there are such colorful works as fairy tales, fairy tales, fairy tales, fairy tales, fairy tales. V.P. Anikin summarizes all of them and calls them fairy-tale literature [3, p.20]. In our opinion, it is impossible to agree with this opinion. Because a fairy tale, whether in the oral tradition or in the written literature, retains its originality to a certain extent. We therefore regard it as an oral and literary tale. But we cannot say that a narrative, myth, parable, story, narrative, and novel in the form of a fairy tale is a mixed form of a fairy tale with other genres. Because these genres have their own criteria. For example, for the novel genre, there is a scope of thinking specific to the novel, a vital-semantic scale, and the formal feature of the fairy tale does not fully cover such a criterion. Now, as for the forms of expression and narration of literary fairy tales, as in the literature of other nations, in Uzbek literature, literary fairy tales are created in the form of prose or poetry. This is not the case with the character of the literary material, but with the poet or prose writer of the creator, his creative inclination and the direction of his talent. Therefore, if a literary tale is created in a poetic form and has a large volume, it is not correct to evaluate it as a fairy-tale, if it is created in a prose form and has a large volume, it is a fairy-tale, a fairytale-novel. This in turn causes great theoretical confusion. Regardless of form and size, a literary tale remains a literary tale. It has its own poetics, interpretation of images, plot structure that cannot be confused with other genres. Literary fairy-tale is a complex aesthetic phenomenon. In order to properly understand the nature of this genre, it is necessary to study in detail the works that fall within its scope, first of all, to determine the sources to which the events of their plot belong. Our observations show that Uzbek literary tales are divided into two groups according to the plot. The first group includes literary tales, the events of which are taken from purely traditional folk tales and creatively reworked by this or that poet or writer. For example, H.Olimjon's works such as "Aygul and Bakhtiyor", "Semurg" belong to such tales. This group also includes such tales as S.Jura's "Blue Carpet" and Sh.Sadulla's "Pea Polvon". Literary tales in the second group include works written by writers and poets for children for didactic purposes based on everyday events. For example, L.N. Tolstoy's "Snow House”, A. Tolstoy's "The Golden Key or the Adventures of Buratino", the tales of the eldest son who stole the money of his aunt, written by Hamza, are among them. In folklore, as well as in literary studies, literary tales are classified as fairy tales about magic, household, and animals, just like folk tales. Of course, such a classification of folk tales cannot be deviated from. Because it is natural that every artist who touches the genre of literary fairy tales creates a new life by choosing and imitating the above-mentioned types of fairy tales. For this reason, literary tales often contain works that involve both magical and domestic tales, as well as images of animals. However, in our view, it would be more appropriate to call fairy tales based on animal images "figurative tales" rather than "tales about animals". Because the animals involved in such tales have a figurative character. For example, Adham Rahmat's tale "The Fox's Trick" has such a sajiya. The genre of fairy tales as a historical and aesthetic phenomenon in Uzbek folklore disappeared in the XIX century, and no force can revive it. Because, the pictorial, expressive possibilities of the traditional fairy tale genre fail to reflect today's reality in all its aspects and complexity. In this regard, if we look at the genre of literary fairy tales, this genre is the artistic processing of real reality materials or folk tales for the education of young people. The fact that literary tales are created mainly for children and adolescents can also be a proof of our opinion. Moreover, the fiction, rhetoric, magic, formulaic narrative typical of traditional fairy tales cannot convince today's people. The main factor in the extinction of the fairy tale genre was the loss of fairy-tale image and fairy-tale confidence in reality. So trying to revive it is of no use. Literary fairy tales, on the other hand, are valuable as a means of instructing children and adolescents and influencing them spiritually and morally through the use of formal elements typical of traditional fairy tales. 


\section{CONCLUSION}

In the article, our views on the modern way of life of traditional fairy tales have led us to the following conclusions: 1 . Oral traditional fairy tales are priceless masterpieces of folk genius, adorning the treasury of our spirituality by educating people in the spirit of noble ideals for many centuries, encouraging them to live with confidence in a bright future. That is why the people strive to save such a rare heritage, which they have created, from disappearing without a trace over the years, and discover various means and methods of its preservation in our spiritual life. 2. One of such means is the recording of traditional fairy-tale specimens, the publication of its beautiful specimens in large numbers, in separate collections. A lot of work has been done in Uzbek folklore in this regard. Dozens of books published in the series "Uzbek folklore", a separate collection of folk tales, are a vivid proof of this. 3. Reviving folk tales in the form of animated and full-length feature films is the most productive way to preserve our traditional fairytale heritage. Nevertheless, it is necessary to intensify work in this direction. 4. More display of fairy tales on TV screens, popularization with the help of radio dramatizations serve as the most effective forms of preservation of traditional fairy tales. This is more important than ever in educating young people in the spirit of diligence, patriotism, humanity and nobility. 5. It would be expedient to revive the participation of folk tales in the activities of amateur art, folklore ethnographic groups. In the future, the development of measures to develop this area will remain an urgent task for folklorists and fans of folklore. 6. Fairy tale plots serve as a leading source on the stages of young audience theaters, puppet theaters. Therefore, the greater involvement of folk tales in the repertoire of such communities should be an important means of educating young people, as well as a key means of preserving traditional tales. To do this, theater directors and folklorists need to work together. 7. Talented writers and poets create interesting literary tales based on the plots of folk tales, loading them with new creative interpretations, which meet the needs and requirements of today's life. In our opinion, the creation of modern literary tales based on the formal capabilities of traditional folk tales will remain the most effective means of preserving our traditional tales.

\section{REFERENCES}

1. Braude L.Yu. History of the concept of "literary tale" // Izvestiya AnSSSR. Literature and Language Series. Vol. 36. 1977. 3. -p. 234.

2. Serov S.Ya. Russian literary tale // Gorodok and snuffbox. Fairy tales of Russian writers. Moscow, 1989.-p. 3-116.

3. Anikin V.P. Russian writers and a fairy tale // Fairy tales of Russian writers. -Moscow: Children's Literature, 1984.-p. 3-22.

4. Alimov S. Formation and development of the genre of literary fairy tales in Uzbek Soviet literature: Dissertation Abstract for the degree of Candidate of Philological Sciences. -Tashkent, 1984.

5. Pomerantseva E.V. Fairy tale // Dictionary of literary terms. Editors-compilers L.I. Timofeev and S.V. Turaev. -Moscow: Education, 1974. -pp. 356-357.

6. Novikov V.I. Fairy Tale // Encyclopedic Dictionary of a Young Literary Cult. -Moscow: Pedagogy, 1988.-pp. 298-304.

7. Azadovsky M.A. Literature and folklore. $-L$, 1938.-p. 56. 